IRA-International Journal of Applied Sciences ISSN 2455-4499; Vol.05, Issue 01 (2016)

Institute of Research Advances

Pg. no. 29-33

http://research-advances.org/index.php/IRAJAS

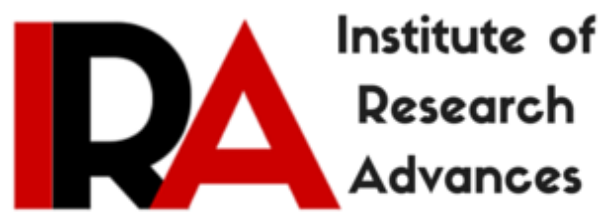

\title{
Carapace Width -Weight Relationship Of Mud Crab Scylla Serrata (Forskal, 1775) Collected From Pulicat Lake, Tamilnadu, India
}

\author{
${ }^{1}$ V. Lakshme Gayathre, ${ }^{2}$ S. Felix \& ${ }^{3}$ R. Durairaja \\ ${ }^{1,2,3}$ Fisheries College and Research Institute, Ponneri, Tamilnadu, India.
}

Type of Review: Peer Reviewed.

DOI: http://dx.doi.org/10.21013/jas.v5.n1.p5

\section{How to cite this paper:}

Gayathre, V., Felix, S., \& Durairaja, R. (2016). Carapace Width -Weight Relationship Of Mud Crab Scylla Serrata (Forskal, 1775) Collected From Pulicat Lake, Tamilnadu, India. IRA-International Journal of Applied Sciences (ISSN 2455-4499), 5(1), 29-33. doi:http://dx.doi.org/10.21013/jas.v5.n1.p5

(C) Institute of Research Advances

\section{(cc) EY-NC}

This work is licensed under a Creative Commons Attribution-Non Commercial 4.0 International License subject to proper citation to the publication source of the work.

Disclaimer: The scholarly papers as reviewed and published by the Institute of Research Advances (IRA) are the views and opinions of their respective authors and are not the views or opinions of the IRA. The IRA disclaims of any harm or loss caused due to the published content to any party. 


\section{ABSTRACT}

Mud crab Scylla serrata form an important fishery in the Pulicat lake, Tamilnadu. In the present study the relationship between carapace width and body weight were estimated as (Log $W=-$ $0.342438+2.914702$ ). The estimated ' $a$ ' and ' $b$ ' value for carapace width and body weight were 0.342438 and 2.914702, respectively. The result showed an isometric growth pattern and significant differences were found between carapace width and body weight in the mud crab collected from Pulicat lake, Tamil Nadu, India.

Key words: Mud crab, Length-weight relationship, Scylla sp.

\section{Introduction}

In crustaceans, as growth progresses certain dimension of the animal's body may grow much more than others, resulting in the phenomenon known as relative growth (Hartnoll, 1974). Studies on relative growth are used to determine changes in the form and size of the abdomen, pleopods or chelipeds during ontogeny. Knowledge of these distinguishing characters and size relationships in sexually mature individuals is of particular importance in the study of commercially valuable crustaceans. Such knowledge can be useful for further studies on the life history of the species and in the development of its fishery, resource management and culture.

Study of width-weight relationship in aquatic animals has wide application in delineating the growth patterns during their developmental pathways (Bagenal, 1978). The width/weight relationships are regarded as more suitable for evaluating crustacean populations (Atar \& Sector, 2003; Gorce et al., 2006, Sangun et al., 2009). Estimates on the relationships are useful to know the variations in expected weight from the known length groups which are in turn the indication of fatness, breeding and feeding states. However, information available on the mud crab is mostly restricted to Scylla serrata (Nandi et al., 1996, Sukumaran \& Neelakantan, 1997). For the present paper, Carapace width- weight relationships of the mudcrab were estimated.

\section{Materials and Methods}

For the study, the samples of Scylla serrata were collected from the Pulicat Lake, the second largest brackish water lake or lagoon in India. Relationship of carapace width and weight were analyzed. Crabs in the intermoult stage with all appendages intact were considered for the study. All materials were analysed in fresh condition. Carapace width $(\mathrm{CW})$ between tips of the longest lateral spines across the middle line between the frontal notch and posterior margin was measured. Individual crab weight was taken in a weighing balance.

The carapace width-weight relationship was estimated using the log form of the allometric growth equation $\mathrm{W}=\mathrm{aL}$ ' (Rickter, 1973), where $\mathrm{W}=$ expected weight, $\mathrm{L}=$ total carapace width, $\mathrm{a}=$ ' $\mathrm{y}$ 'intercept or the initial growth co-efficient and $b=$ the slope or growth co-efficient. The values of constants of ' $a$ ' \& ' $b$ ' were calculated by the least square method. The differences in the carapace width-weight relationship between sexes were tested by ANOVA.

\section{Results and Discussion}

A Scatter diagram (Fig 1) was obtained by plotting the width against weight of individual crabs. From the closeness of the scatter and the Parabolic nature of the plot a good relationship was found between width and weight as also the suitability of fitting the exponential formula $\mathrm{W}=\mathrm{aL}^{\mathrm{b}}$ to the data. The logarithmic equations derived is

$\log \mathrm{W}=-0.342438+2.914702$.

The coefficient of correlation (r) obtained for the carapace width and weight of the mud crab is 0.97 (nearly equal to 1), indicating that the values were significant. Hence, a high degree of positive correlation was evident between width and weight. The exponential value of the width-weight relationship was 2.914702 , thereby indications nearly an isometric pattern of growth. 
However for an ideal organism which maintains its shape throughout the value of ' $b$ ' will be ' 3 ' (Allen, 1938). But in a number of organisms the value of ' $b$ ' lies between 2.5 and 4.0 (Martin, 1949). The present findings are in accordance with those of Sukumaran and Neelakantan (1997) in Portunus pelagicus. Cheewasedtham reported that the relationship between Carapace Width and Weight was Log W=- $0.00033+2.92$ in Scylla serrata. The relationship between carapace width and weight was $\log \mathrm{W}=-0.147+2.567$ in Sudanonautes africanus were reported by Bello-Olusoji et al., (2009). The values of b ranged from 2.04 to 3.24 for Callinectes sapidus (Stickney, 1972). Growth was isometric (3.04) value in the length-weight relationship study of portunid crab, Callinectes pallidus (Bello-Olusoji et al., 2006). Change of ' $b$ ' values depends primarily on the shape and fatness of the species. Various factors may be responsible for the difference in parameters of width-weight relationships among seasons and years, such as temperature, salinity, sex and maturity stage. The Carapace Width and Weight relationship showed that Scylla serrata is a good candidate species for aquaculture. It is also essential for proper assessment and management of resources in the Pulicat lake.

\section{Acknowledgement}

I express my sincere gratitude to Dr. S. Felix, the Dean, Fisheries College and Research Institute, Ponneri for his encouragement and for providing the facilities for the research work.

\section{References}

- Allen, K. R. (1938). Some observations on the biology of the trout (Salmo trutta) in Widernere. J. Anim. Ecol. 4: 264 - 273.

- Atar, H. H. \& Sector, S. (2003). Width/length-weight relationships of the blue crab (Callinectes sapidus Rathbun, 1896) population living in Beymelek lagoon lake. Turkish Journ. vet. Anim.Sci. 27: 443-447.

- Bagenal, T. (1978). Method for assessment of fish production in fresh waters (3rd ed - IBP Handbook), 3. Blackwell Scientific Publications, Oxford. 1-365.

- Bello-Olusoji, O. A., Oyekanmi,M., Afunmiso, O.M., and Ozorewor, M. O. (2006). Lengthweight relationship and stomach content of Portunid crabs, Callinectes pallidus (de Rochebrune, 1883) from the Gulf of Guinea. Bowen J. Agric. 3(1): 65-72.

- Cheewasedtham, C. (1990). Fishery biology of mud crab, Scylla serrata in Klong Ngao Mangrove Forest, Ranong province. M.Sc. Thesis, Chulalongkorn University, Bangkok, Thailand, pp: 142

- Gorce, G., Erguden, D., Sangun, L., Cekic, M., and Alagoz, S. (2006). Width/length and relationships of the blue crab (Callinectes sapidus Rathbum, 1986) population living in Camlik Lagoon Lake (Yumurtalik). Pakistan Journ. Biol. Sci. 9(8): 1460-1464.

- Hartnoll, R. G. (1974). Variation in growth pattern between some secondary sexual characteres in crabs (Decapoda, Brachyura). Crustaceana. 27: 131-136.

- Martin, W.R. (1949). The mechanics of environmental control of body form in fishes. Univ. Toronto. Stud. Biol. 58:1-91.

- Olusoji, O.A.B., Anifowose, O. J., and Sodamola, M.Y. 2009. Length-Weight Relationships, condition factor and fecundity of the West Africa Freshwater Crab, Sudanonautes africanus (Milne-Edwards, 1883), in Western Nigeria. West African Journal of Applied Ecology. 16: 65-74.

- relationships of the blue crab (Callinectes sapidus Rathbun, 1986) population living in Camlik Lagoon Lake (Yumurtalik). Pakistan Journ. biol. Sci. 9(8): 1460-1464.

- Rickter, W. E. (1973). Linear regressions in fisheries research. Journ. Fish. Res. Bd Canada. 30(3): 409-434.

- Sangun, L., Tureli, C., Akamca, E., and Duysak, O. (2009). Width/length-weight and widthlength relationships for $8 \mathrm{crab}$ species from north-Mediterranean coast of Turkey. Journal of Animal and Veterinary Advances. 8(1): 75-79.

- Stickney, R.R. (1972). Length-Weight Relationships for several Fishes and Invertebrates in Georgia Coastal Waters with Condition Factors for Fish Species. Skidaway Institute of Oceanography Savannah, Georgia, USA. 
- Sukumaran, K.K. and Neelakantan, B. (1997). Length-weight relationship in two marine portunid crabs, Portunus (Portunus) sanguinolentus (Herbst) and Portunus (Portunus) pelagicus (Linnaeus) from the Karnataka coast. Indian Journ. mar. Sci. 26(1): 39-42. 
(Figures \& Tables)

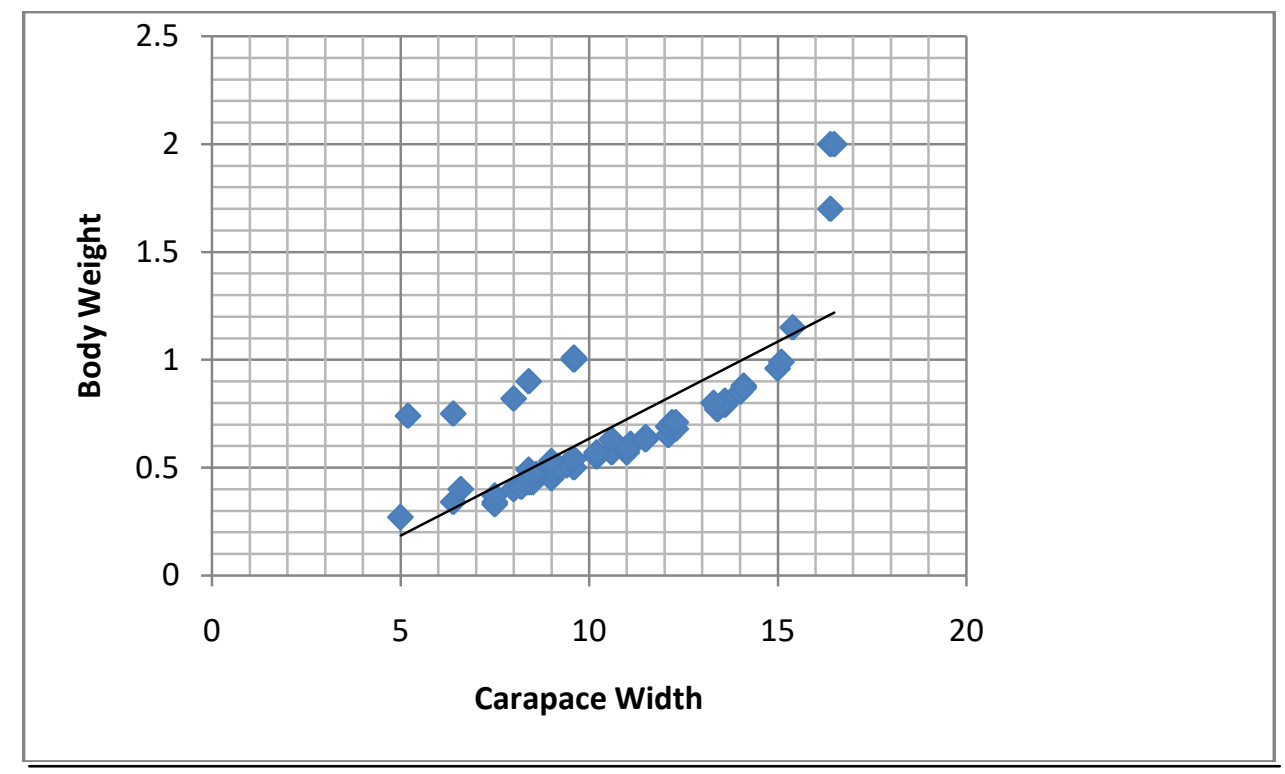

Fig 1: Logarithmic relationship between carapace width and body weight of Scylla serrata collected from Pulicat lake. 